\title{
2
}

\section{All the world's a stage: Paris 1855}

n 1855 Parisians believed that their city was the centre of the world. On 15

May of that year emperor Napoleon III opened the second World's Fair, which would attract over five million visitors. To Napoleon, this exposition was the international affirmation of his reign. Charles Louis Napoleon Bonaparte, the third son of Louis Napoleon Bonaparte, king of Holland, was elected president of the new French Republic in 1848. In 1852, he abandoned his republican ideals and had himself crowned emperor Napoleon III of France. He ordered the construction of the Palais de l'Industrie, a magnificent structure of glass and iron between the Champs-Élysées and the river Seine. The design was reminiscent of the Crystal Palace in London, which had been built for the Great Exhibition of 1851. The colossal Palais provided accommodation for the 21,779 industrial exhibitors. At 250 metres long, 108 metres wide and 35 metres high, it was one of the largest, if not the most elegant, modern structures in Paris according to the Baedeker of 1878. The exposition's 2,175 fine art entries were housed in a separate building, the Palais des Beaux-Arts. The construction of the palaces was an integral part of the grandiose urban renewal project that the emperor asked prefect Georges Haussmann to carry out in 1853. The visitors to the World's Fair witnessed the beginning of a demolition and construction craze that would grip the city for years to come.

Napoleon also employed less peaceful means to raise the prestige of his empire. In 1854, France and Britain declared war on Russia. The Crimean War would reach a tragic low point with the siege of Sevastopol, which coincided with the Paris exposition. The siege came to an end when the French breached the Malakoff bastion on 8 September, two days before the opening of the second international statistical congress.

The congress delegates were not especially concerned with the Crimean War. Nevertheless, Carl Friedrich Wilhelm Dieterici, who represented the 
Prussian kingdom in 1855 as he had in 1853, observed a bellicose mood among the French. ${ }^{1}$ The name of General Pélissier, the hero of the storming of the Malakoff, was on everyone's lips. Dieterici noted that popular dramas and children's theatre showed 'that the French are a bellicose people'. He sensed that the entire French government exuded an aura of command and obedience. It is perhaps astonishing that such descriptions should flow from the pen of a Prussian official, but they reveal the simmering tensions between Prussia and France that slowly but surely were infecting international and personal relations. Dieterici's report of his journey to Paris is permeated with the intense rivalry that was brewing between these two countries. Wherever he discerned economic growth in France, he sought evidence of even greater prosperity in his home country. He admired the French silk industry, but could not resist noting that Prussian silk was of extraordinary quality. He noted, with undisguised pride, that the French held German science in high esteem.

Dieterici was not particularly complimentary about the Paris statistical congress. He thought the programme and the issues presented by the participants were 'too French'. He criticised the lack of scientific principles and the excessive bureaucracy. His criticism is surprising since just two years earlier he had complained about the lack of administrative expertise and the academic mentality of the French and the Belgians. In his letter of 4 May 1855 to Alfred Legoyt, director of the Statistique Générale de France, he had revealed nothing of the scientific aspirations that he emphasised in his report on the congress to the Prussian interior minister. One might wonder what Dieterici's actual objectives were. One of his proposals was to expand transport statistics by including the length of village streets as well as that of major roads, railroads and canals. While this may have been a useful suggestion, it was not an ingenious idea of a great scientist (which he clearly thought he was). ${ }^{2}$

The absence of the peacemaker, Adolphe Quetelet, may be one reason for Dieterici's about-face and less-than-conciliatory attitude towards the French. The great pioneer of European statistics had suffered a stroke in July 1855 and was too ill to travel. Quetelet was a master at engineering compromises and striking the right tone. His absence was nearly as palpable as his presence would have been.

\section{Charles Dupin}

The programme for the second international statistical congress was compiled by a commission under the auspices of the French Ministry of Agriculture, Trade and Public Works. Unlike Belgium, France had no permanent central commission for statistics. The ad hoc commission did not meet until April 1855, so there was little time for thorough preparations. Charles Dupin's report on the provisional programme struck a decidedly patriotic tone. That always worked.

Dupin was born in Varzy (near Nevers) in 1784 and educated at the 
Polytechnique. During the First Empire, he pursued a career as a naval engineer. His father had been a member of the National Assembly during the revolutionary period and later became a prefect, so it is not surprising that Dupin - like his elder brother André-Marie - had political ambitions. In 1827, he entered Parliament as a liberal. In and outside Parliament, he positioned himself as a naval specialist and a man of extensive knowledge of socio-economic issues. In 1820, he published the six-volume Force militaire de la Grande-Bretagne, followed by Force Commerciale de la Grande-Bretagne in 1826 and Forces productives et commerciales de la France in 1827. These works were steeped in the German tradition of descriptive political science, but also had a numerical foundation. In any case, they gave Dupin national and international prestige.

Forces productives et commerciales contained a shaded map showing the disparities in the state of education in each department. This 'Carte figurative de l'instruction populaire de la France' was the first modern statistical map. It showed the relationship between the entire population of an administrative unit (in this case, the departments) and the number of children in school. The lighter the shading, the more children there were in school relative to the total population of the department; the darker the shading, the fewer children there were in school, or - in the words of Dupin - the more people were needed to send one child to school. In fact, the map gave as much insight into the state of education as the distribution of ignorance.

Dupin made a significant contribution to the dubious practice in statistical geography of dividing France into the virtuous North and the idle, wicked South. By including statistical data about each part of the country at the bottom of the map and in the text of the book, he accentuated the differences between the two regions of France, which were separated by an imaginary line running from Saint Malo to Genève. Southern France was depicted in darker shades because of the smaller percentage of children in school, but also because it had relatively fewer schools, won fewer prizes at industry expositions, had a lower mean household income and much lower tax revenues and, in general, had less 'production capacity'.

Quetelet wrote about Dupin's graphical innovation in his journal, Correspondance mathématique et physique, and announced that an education map of the Netherlands was being prepared. Like France's southern departments, the south of the Netherlands was obviously straggling. ${ }^{3}$ Édouard Smits, the secretary of the statistical commission for the United Kingdom of the Netherlands, also cited Dupin's work in his discussion of the state of education in the northern and southern Netherlands. 'He has', Smits wrote of his French inspirator, 'brought about a great leap forward in science; he has used the figures to explain the morality, enlightenment and glory of his countrymen.4

Dupin's moral statistics were part of the liberal, intellectual movement that had defined the statistical environment in France since the 1820s. Ideas about morality were rendered into statistical categories, thereby creating a new reality expressed in 'hard' numbers. This was a reality fraught with threats to bourgeois life, but it showed where state intervention or private initiative was needed to 
stave off danger. The Brussels edition of Forces productives et commerciales de la France contained an homage to the inhabitants of Southern France that the government censor had omitted from the French edition. The south was first defined as a statistical unit and was then given a model 'to be followed prudently'. The model was the north of France: 'a part of the kingdom that has benefited from a long series of events, but especially from its proximity to peoples such as the Britons, the Swiss and the Dutch who are industrially advanced and highly satisfied with their institutions, while your only neighbours are the peoples of Spain and Portugal, of Sardinia and Africa, who were left behind long ago and are underdeveloped due to bad laws and bad governments. ${ }^{5}$

It was no coincidence that Dupin was so deeply engaged with the working class and the idea that its members could be guided along the right path by a humane state and targeted paternalism. Industrialisation and the rise of the proletariat posed direct threats to the bourgeois order. Dupin made enthusiastic use of numerical data in dealing with this subject. The goal of his investigations into the fortunes and misfortunes of the working class could be inferred from the titles of his writings on this matter: Sur le sort des ouvriers consideré dans ses rapports avec l'industrie, la liberté et lordre public (1831), Harmonie des intérêts industriels et des intérêts sociaux (1833) and L'avenir de la classe ouvrière (1833).

By 1855 Dupin had reached the respectable age of 71 . His years mattered. He had been appointed to the Senate by Louis Napoleon in 1852, and he was a prominent rapporteur for the imperial commission established to organise the World's Fair of 1855. Dupin opened his report on the programme for the 1855 statistical congress by pointing out how important it was for France - which had an illustrious statistical tradition - to play a leading role at the congress. Nationalism seeped into the debates on statistics and morality virtually unnoticed. Dieterici's criticism of French chauvinism (which was rather like the pot calling the kettle black) was not wholly unfounded. It was obvious to the commission and Dupin that France could claim superiority over other parties when it came to government statistics. Dupin made that perfectly clear. The French government had been ordering intendants in the provinces to gather statistical information since the time of Louis XIV. Under Napoleon I, official statistics received new impulses, and the French Restoration sparked important initiatives, which were imitated by the Belgians and the British. In Dupin's view, the conquest of Algeria was also a victory for statistics: 'Statistics concerning that land, which have been gradually perfected, constitute a periodic commendation, expressed in facts, for the capacity of a great nation to extol the blessings of civilisation in a region that not 25 years ago was in a state of utter barbarism and infancy. ${ }^{6}$ Dupin could not resist mentioning the departmental education maps that had been produced in the past decade, patterned after his example. Initially, his maps drew a great deal of criticism, particularly from the departments that were lagging behind, but the number of schools increased gradually and the map's shadings become lighter and lighter, 'so bright that there was almost no need to publish it.' His recital continued in this vein. The message 
was clear: a presentation of France's achievements in statistics would have such a salutary effect on other countries that they would be compelled to adopt French statistical practice.

\section{An assessment of French statistics}

Dupin's linear progress diktat was well suited to the Napoleonic climate. The statistical traditions of France, however, were much more complex than his argument suggested. Influenced in part by the political regime changes that followed the Revolution, statistics in France underwent a period of turbulent development. Statistics had a long history as an instrument of the state. During the ancien régime, the military and financial vicissitudes of the kingdom regularly motivated the king and his ministers to ask the provincial authorities to provide numerical information. However, confidentiality was essential; the royal court was ultimately the only beneficiary of these statistical investigations. In the course of the eighteenth century, various multidisciplinary studies combining political, economic and geographical research were published, many written by members of the Académie des Sciences, which was preparing the way for statistics as a science. Prominent scholars like d'Alembert and Condorcet were developing what was intended to be an explicitly political science. Condorcet called it 'social mathematics'. Around 1760, scholars and public servants began an intensive exchange of ideas. Condorcet, for example, had a close relationship with Turgot, a physiocrat and the financial genius behind Louis XVI. New quantitative methods (e.g. the birth rate multiplier discussed in Chapter 1) were tested but vanished quickly after 1789. At any rate, they were not incorporated into government statistical practice. The theory of probabilities and other complex mathematical methods were being used in the life insurance business and in gambling theory, but statistics would follow another path for the time being.

There is no simple explanation for this. Keverberg's explicit rejection of Quetelet's proposal to conduct a population count based on a kind of sampling (discussed in the previous chapter) echoed the divergence of opinions that marked the last decade of the eighteenth century. Enlightened thinkers, in particular philosophers and mathematicians, were severely shaken by the French Revolution. The rapid succession of political upheavals that began in 1789 undermined their faith in the propensity towards reason, which may have been the preserve of the elite but nevertheless could serve as a moral guide for all. While the eighteenth-century thinker regarded society as a collective of rational individuals and, consequently, an organism governed by order, his nineteenth-century successor saw a society that was guided by order despite the irrational nature of the human beings living in it. Eighteenth-century political probability theory evolved into nineteenth-century statistics, but underwent a radical metamorphosis along the way. ${ }^{8}$

Science was not solely responsible for this transformation. The French 
Revolution paved the way to a well-ordered state, which may not have been immediately evident in practice, but the blueprint was there. In 1789-1790 the National Assembly designed a hierarchical, uniform government structure that was meant to facilitate effective centralised control and, at the same time, bring government and the people closer together by means of elections and public education. The government's division of the country into departments was an important step in the process and dissolved the traditional provincial boundaries, forging new territorial loyalties. This turned out to be one of the most enduring reforms of the Revolution. In the nineteenth century, the departments were an essential component in statistical research. The statistical exertions of the revolutionary state were initially limited to research aimed at exploring the new territorial reality. During the Consulate period, at the end of 1799, the government stepped up its statistical research activity, which was coordinated by a statistical bureau operated by the interior ministry. In 1802 the bureau was incorporated into the ministry's Secretariat General and given its own domain, separate from the other ministerial divisions. As such, it became 'the central memory of the state. ${ }^{9}$

\section{The Napoleonic moment}

The statistical bureau rejected probability theory, despite the presence of the mathematician Étienne Duvillard, who had moved in the same circles as Condorcet before the Revolution. In 1806, Duvillard served briefly as director of the bureau, but it was already clear to him that mathematical methods were unwelcome. Jean-Antoine Chaptal, France's interior minister from 1800 to 1804, had firmly rejected Duvillard's proposal to establish a Bureau des Calculs Scientifiques, 'where facts are verified, where essential correlations and laws are sought through mathematical analysis or otherwise deduced if they cannot be identified through direct observation. ${ }^{10}$ In the minister's view, a bureau of this nature and the proposed methods tended too much towards secrecy and held too little promise of producing genuine empirical knowledge.

Due to their vision of good administration, the Consulate regime had a preference for general, descriptive statistics, if necessary numerical but never obtained through deduction. They wanted a precise analysis of where the departments stood and how regional diversity compared to that of the nation. The Statistique Générale de la France, Chaptal's large-scale comparative statistical survey launched in 1801, typified the goals of the Consulate. The prefects placed in charge of the departments in early 1800 (a reform with long-lasting effects) were ordered to write descriptive reports in accordance with a fixed plan. They were instructed to address five main topics: topography, population, social circumstances, agriculture and industry; the minister also asked the prefects to compare the pre-1789 situation to the current state of affairs. The circular of the 19th germinal in the revolutionary year IX explaining the project was followed by 25 tabular forms, each accompanied by pages and pages 
of instructions. ${ }^{11}$

Chaptal's ambitious goal was to produce an highly detailed inventory of France. Precision was the primary requirement: 'saying nothing is a thousand times better than saying something that is incorrect', he wrote to his prefects. ${ }^{12}$ The farthest reaches of the country were to be described and Paris would be given access to all the information amassed. The administrative structure and the design of the statistical survey corresponded perfectly. The prefects were well placed to furnish accurate and detailed data; the possibilities were too enticing to be left unexploited. Chaptal rebuked a prefect who thought it would suffice to base his overview of the taxes levied in his department on an average value: 'In this case, using a proportional average will not suffice; that would teach me nothing I do not already know, that would not reveal what I most urgently seek, namely the subtle physical and moral distinctions that distinguish the various parts of France from each other.' ${ }^{\prime 3}$ Knowledge was power, especially when it was comprised of empirical facts.

In many ways, Napoleonic statistics foreshadowed the form that statistics would take as the nineteenth century progressed. The same bureaucratic hierarchy that was used to carry out statistical investigations could be used to intervene in social life. Statistics legitimised the importance of the state. For a while, there was very little distinction between the science of public administration and statistics. In his authoritative essay on statecraft (three editions between 1808 and 1812), Charles Jean Bonnin wrote: 'Statecraft and statistics, which are mutually enlightening, will contribute to the internal prosperity of states. Like physicists discerning natural laws from the constant facts of nature, so shall governments seek in the knowledge of the facts the remedies specific to the needs of the nations.' ${ }^{14}$

'Governing requires knowledge' was the idea behind the Napoleonic state, and a notion to which the liberal state of the future could subscribe. This seemingly simple aphorism was not as easy to put into practice as one might think, even through the agency of a state as strong as the Napoleonic one. Napoleon had the same problem that liberals encounter when they in power: without the cooperation of the people - and first and foremost the local elites - it would be nigh on impossible to accumulate useful knowledge, let alone undertake specific actions.

The interaction that arose between state and population affected the knowledge that statistical investigations produced. The local elites - notables, landowners and civil servants - who supplied the factual information could not have had a radically different perspective from their principals. They were tied to the classifications and categories they were given to work with. Moreover, it was virtually inevitable that the reports would confirm the divisions between the enlightened statistics compilers and those being described, between the elites and the general population. Descriptions of society indicated the direction of social change. The chasm that existed between government and the governed became increasingly obvious. The elites were self-reverential, were incapable of critical self-reflection and remained largely invisible. The people 
were the main focus of attention, in part because they were easy to describe, but primarily because they had to be governed and improved. Connections were often drawn between the national character and the physical environment. The observations of the prefect of Ariège (near the Pyrenees) on the local population are typical: 'The inhabitant of Ariège is by nature good and obliging, but also cold, severe and cautious ... He is frugal and patient, and almost impervious to hardship ... Religious fanaticism appears to be at the core of his character. ${ }^{15}$ Generalisations of this kind remained in vogue throughout the nineteenth century (and beyond).

There was another important continuity: Chaptal's statistical topography was not a resounding success. The state was not strong enough and society was not cooperative enough for the project to succeed. Statistics faced constant resistance and aversion. This was no different under Napoleon and, given the frequency of requests for statistical information, the obstinacy of the provinces was completely understandable. The prefects often mentioned the respondents' attempts to dodge the government's constant demand for numbers. And in some cases, they helped to manipulate the figures. In 1805, Chaptal's initiative ultimately resulted in just 47 statistical memorials (out of 111 departments, of which 25 were outside France). ${ }^{16}$ This was not an accomplishment that a wellorganised state would be proud to claim. The experience that some prefects gained in the process, however, had a long-lasting effect. Gilbert Chabrol de Volvic was responsible for compiling a statistical report on Montenotte in Northern Italy; he made a name for himself later as prefect of the Seine during the Restoration, when he applied his professional skills to produce Recherches statistiques sur la ville de Paris et le département de la Seine (four volumes, Paris 1821-1829). As we will soon see, this work was a treasure trove for the 'moral statisticians'.

The end of Chaptal's tenure as interior minister in 1804 marked a transformation in Napoleonic statistics. The practice of producing descriptive departmental statistics made way for targeted, strictly numerical, uniform investigations that directly served the interests of the state. ${ }^{17}$ The wars, the continental blockade and the economic crisis strengthened the autocratic elements of the Napoleonic state, and statistics was caught in the current. Interest in broad topographical matters all but disappeared; only meteorological observations were continued because of their importance to agriculture. Surveys were streamlined and covered only a limited list of strictly defined topics, such as the navigability of inland waterways, salt, olives, chestnuts, textiles, agricultural land and livestock. ${ }^{18}$

\section{The guises of statistics after 1815}

If the Consulate and Empire periods were the fat years for French statistics, the reign of the Bourbon monarchs (1815-1830) could be regarded as the lean years. Nevertheless, the Restoration was not just a time of statistical decline. 
There was no place for a central statistical bureau under the monarchy, but the accumulation of statistics went ahead as usual in the departments. Most mayors continued to produce routine reports on births, marriages, deaths, migration and taxation, and with equal regularity the prefects incorporated the data into their official correspondence. But no national statistical publications of any consequence were produced.

The continuity of statistical research at provincial and local level is most apparent in the Recherches statistiques sur la ville de Paris et le département de la Seine, which prefect Chabrol de Volvic helped to compile. Chabrol's tenure as prefect of Paris from 1812 to 1830 is an exceptional example of bureaucratic continuity. In 1817, he ordered an extensive census of the French capital that was reminiscent of Chaptal's statistics project. The survey covered population, climate, geography, institutions and the economy. In 1818, an autonomous bureau for records and statistics was established for the Seine prefecture. Managed by Frédéric Villot, the bureau was involved in implementing the census and processing the data. Villot himself made an important contribution to the Recherches Statistiques. In the preface he wrote that statistical investigations were a core element of public administration. And, he continued, 'it often occurs that vital administrative questions arise which could not be probed deeply without resorting to statistical information. ${ }^{19}$ This was clearly reminiscent of Napoleonic practices. At the same time, Chabrol and his colleagues distanced themselves from the politics of the latter years of the Empire by publishing figures and interpretations of the numbers.

In 1818, Chabrol issued a report to the interior minister about the Paris census of the previous year and had it published in the Recherches Statistiques. He emphasised that the count was better in many respects than previous ones. The first improvement was that numerical statements noting the number of people in a dwelling were replaced by complete name lists of all inhabitants. In addition to people's names, the new lists included their age, sex, marital status and occupation. Separate sheets were created for each household. Chabrol reported that there were some 200,000 sheets in total. The second improvement was the appointment of special officials to conduct the door-to-door survey. The 150 officials were 'all persons of irreproachable conduct with positions in public service.20 The entire operation was completed within ten days to avoid potential counting duplications due to people moving house. Special measures were taken for hospitals, hotels, military barracks and the like. The Dutch and Belgian population censuses of 1829 and 1846 respectively, and the instructions regarding the population registers in those countries, were no doubt based on the Paris operation.

Not only did Chabrol provide a count of the city's inhabitants and a series of sheets containing the most essential information about the population, he also ordered his staff to process the statistical data. For example, they compiled reports summarising data on sex, age and marital status of the inhabitants by street and district. This made it possible to compare different areas of Paris.

Chabrol was also interested in the relationship between the number of 
births and the total population (a relationship expressed by the 'multiplier', as explained in Chapter 1). Understanding this relationship would make it possible to 'identify the progressive variations in the population and the increase that has taken place since the end of the seventeenth century. ${ }^{21}$ Quetelet was no doubt aware of this passage when he proposed a count using the multiplier in the United Kingdom of the Netherlands. His proposal, however, ignored the fact that a full census had been conducted in Paris first.

Alongside Villot and Chabrol, the mathematician and physicist Joseph Fourier was an authoritative co-author of the Recherches statistiques. He wrote several pieces in which he demonstrated that large sets of population data revealed patterns. There can be no doubt that Fourier's contributions provided inspiration for Quetelet's first statistical works on the Kingdom of the Netherlands. The ideas Fourier expressed in the Recherches statistiques are also reflected in Quetelet's Sur l'homme (1835). But Quetelet was not the only one who drew on the insights and comparative material from the statistics on Paris.

The physician Louis Villermé wrote and published an extensive dissertation on the first volume of the Recherches statistiques in 1821. The census data and the related statistical studies were a goldmine for Villermés project on social medicine. As an army surgeon under Napoleon, he had spent a great deal of time on the battlefield, where he witnessed how quickly epidemics could take hold and how important good hygiene was. After the Napoleonic wars ended, he turned his attention to the role of medicine in peacetime. In an article from 1818, 'On hunger and its impact on health in former theatres of war', Villermé combined his experiences as an army medical officer and as a socially engaged researcher. ${ }^{22} \mathrm{He}$ was a member of several reformist associations and wrote reports in which he used government statistics to explain aspects of population dynamics. He frequently discussed trends in birth and death rates.

Villermés articles about difference in the mortality rates of the rich and poor in Paris and in France are typical examples of his approach. It will come as no surprise to us that he discovered pronounced disparities. In the early nineteenth century, such observations invited wild speculation about the future of social relations. At the time, there were fierce debates going on about whether climatological and geographical circumstances affected morbidity and mortality and whether the social environment had an even greater impact. The correlation between progress and health was another topic of discussion. Was it the case that public health improved as society developed, or did progress foster idleness or enflame passions and, if so, did this adversely affect people's health? These were important issues to the emerging bourgeoisie.

In Villermés opinion, such questions could best be answered by looking at the numbers. He gradually came to believe that poverty was the most malevolent factor and managed to convince his generation of sanitarians that his ideas were right. The cholera epidemic of 1832, which claimed 18,000 victims in Paris alone, was in many ways a test case for the sanitary movement in France. Though Villermé had worked hard to position himself as a social statistician, in 1832 he returned to medicine and joined in the battle against cholera. Unfortunately, 
medicine was virtually powerless against this devastating disease. He made an important contribution to the report on the epidemic that raged in and around Paris. A special commission compiled the report by order of the state. Villot, as director of the statistical bureau of the prefecture, sat on the commission. ${ }^{23}$ Social medicine and statistics were now inextricably linked.

Quetelet was deeply interested in Villermés work and initiated a public exchange of letters with the Frenchmen in Correspondance mathématique et physique. Quetelet adopted Villermés methods in his own research on monthly fluctuations in birth and death rates, and was receptive to social explanations. Each man strengthened the other's conviction that population dynamics were subject to laws. The contact between Quetelet and Villermé demonstrates the significant role that statistics played in how public health theories developed in the first half of the nineteenth century. The Annales d'hygiène publique, first established by Villermé and several other French physicians in 1829, confirmed year after year that quantification was an important instrument for controlling public health. In his principal work, Sur l'homme, Quetelet used a great deal of data that he and others had already published in the Annales d'hygiène publique.

A movement of 'moral' statisticians gradually took shape after 1830. Moral statisticians were interested in connections between poverty and other social ills on the one hand and disease, death, education and similar issues on the other. They saw unvarying patterns in nearly everything. Rates of suicide, insanity and crime showed the same astonishing regularity, at least in their eyes. In 1833, André Michel Guerry published his popular Essai sur la statistique morale de la France, which attracted attention from beyond France's borders. Like Dupin he was partial to graphical representations. And like Dupin in 1829 he published several maps of France showing the relationship between education and crime rates. ${ }^{24}$ In his monograph of 1833 he wrote that good education could by no means guarantee a reduction in crime (though he had come to this conclusion in a somewhat arbitrary fashion). Education, he decided, was 'an instrument that can be used for good or for evil. ${ }^{25}$ This notion contradicted the commonly held assumption that the departments where education was poorest had the highest crime rates.

Guerry and other moral statisticians took an extraordinary interest in the topic of suicide. Their unremitting attention for this social phenomenon, this 'moral disease', resulted in a growing body of detailed and precise statistics on the subject. Émile Durkheim's famous book on suicide, published in 1897, was based on over fifty years of intense debate on the issue.

The work produced by Dupin, Villermé, Guerry and others would have been virtually inconceivable without the ever-expanding series of government statistics publications. The Ministry of War had been producing the Comptes présentés au Roi sur le recrutement de larmée, an annual account of matters related to conscription, since 1819 and the Ministry of Justice began publishing criminal statistics regularly in 1827 . The Compte général de l'administration 
de la justice criminelle, the longest-running and most homogeneous statistical series on crime, served as a model for many other countries and was a source of raw data for the development of the science of criminology. ${ }^{26}$ Guerry based his statistical maps of 1829 on it. Primary education statistics were published from 1831 onwards under the auspices of the Ministry of Education. All of these series had their roots in earlier initiatives, but the regularity with which they were published gave the science of statistics an unprecedented impulse.

The political climate that emerged after the revolution of 1830 , which ushered in the July Monarchy, was more favourable for the development of statistics than that of the Restoration. The government strove to adopt legislation that would enable social forces to develop unencumbered. To achieve its goal, the government needed to understand these forces. There was more intellectual freedom, as evidenced by the revitalisation of the Académie Royale des Sciences Morales et Politiques in 1832. One of the Académie's five divisions was devoted to political economy and statistics and its members included illustrious figures like old Abbé Sieyès, who returned from exile in Belgium in 1830, and Charles Maurice de Talleyrand, Auguste Comte, Dupin and Villermé.

The battle against pauperism was an important theme within the Académie des Sciences. In 1834 the minster of education, François Guizot, asked Villermé and the Académie to conduct a statistical investigation of factory workers. The study was published in 1840 under the title Tableau de l'état physique et moral des ouvriers employés dans les manufactures de coton, de laine et de soie. Together, Villermés substantial research report and Edwin Chadwick's Report on the Sanitary Condition of the Labouring Population of Great Britain (1842), which is discussed in Chapter 3, constitute a sanitarists' manifest of the first order. Villermés work was based on numerous visits in loco, contained a myriad of tables and typified the role that statistics was playing at the time as a science of social facts. Tables and charts were a widely accepted method of representing data and lent gravitas to opinions. Villermés Tableau was often quoted in debates on the child labour law that parliament ultimately passed in 1841, after it had been watered down.

In 1835 parliament decided to make funds available to set up a statistical collection, demonstrating that statistics was gradually regaining its position within the central state. Two years earlier, Adolphe Thiers, who was minister of trade at the time, had commissioned a translation of the statistical work of Britain's Board of Trade (Tableau du revenu, de la population, du commerce, etc., du Royaume-Uni et de ses dépendances, Paris 1833). His aim was to underline the usefulness of a similar publication, namely a new Statistique Générale de la France. Alexandre Moreau de Jonnès was put in charge of the project and would run the bureau of the SGF until 1852.

Moreau had a fairly formalistic view of statistics. 'Statistics is the science of social facts, expressed in numerical terms,' he wrote in an essay in $1847 .{ }^{27}$ He believed that statistics did not exist without numbers, and if the numbers bore no relation to social facts, they were not true statistics. He did not think much of the sanitary movement. Though he shared the sanitarians' appetite for 
statistics, he preferred absolute numbers and wanted nothing to do with probabilities or any other method of calculation that detracted from the purity of the number as a direct expression of social reality. He wanted to present only hard numbers to the minister, not statistical laws or patterns deduced from the numbers. The sections of the Statistique Générale de la France concerning the territory, the population, the economy and public administration (the first series was published between 1835 and 1852 in thirteen parts) largely met Moreau's wishes: a lot of numbers, no debate and no controversial subjects. The interests of the moral statisticians were ignored.

Nevertheless, the official statistical publications, edited by Moreau, did in fact express certain ideas about social order. First, the large-scale use of the machinery of government (the prefects facilitated all the surveys) demonstrated great confidence in bureaucracy. The relationship between the state and statistics that had evolved during the Napoleonic period was restored. Second, the Ministry of Agriculture and Trade, which supervised the government statistics, wanted above all to learn more about France's public resources. In its circulars, the Ministry of Agriculture and Trade emphasised that the surveys had no fiscal objectives, but the accumulated information was a welcome source of knowledge for the Ministry of Finance.

The government began collecting statistics on industry in 1839, but stopped after a year because the public - factory owners in particular - were convinced that the government was laying the groundwork for a new tax. The industrial survey was resumed in 1845 , not only as a quantitative investigation of the size and dispersion of factories, but also as a study of the influence of industrial capitalism and the size and composition of the working class. As previous surveys had revealed, asking the question was (almost) tantamount to answering it. In 1839, all workshops employing twenty or more labourers were defined as factories; but during the course of the survey, the threshold was lowered to ten, drawing a line between industry and trades, 'arts et métiers', which would be included in a future survey. The prefecture kept copies of the forms that were filled in for each factory. Knowledge about the dispersion of workers was always useful.

\section{Unity and diversity at the congress of 1855}

Moreau de Jonnès had resigned as director of the bureau of the Statistique Générale in 1852 and so did not participate in the congress, but did remain active in the Académie des Sciences. He told Dieterici that the congress was hostile to science and avoided the real issues that the international statistics community needed to tackle. 'C'est le pouvoir qui fait la chose' was his devastating judgement. Villermé, who was well over seventy years old, put in an appearance but did not play a prominent role.

By the time the second international statistical congress began in 1855 , statistics had acquired a permanent place in the machinery of government, in the 
academies and in public opinion in France. Statistics survived both the revolution of 1848 and France's transition from a republic to the Second Empire, but there was still little consensus about its subject matter and objectives. The emperor was primarily interested in the grandeur of the nation. The executive branch needed a numerical description of society in order to organise and control it. The scientific community wanted to go further, to uncover probabilities and patterns, in short, to organise progress. Numerous statistical essays had been published by then, and each defined the concept of statistics differently.

In the year of the Paris congress, Achille Guillard - teacher, engineer, botanist and statistician - coined a new term, 'demography'. His ambition was to establish a new science. He saw demography, or 'human statistics', as the confluence of the many streams of statistical thought:

Is it not for the sake of humanity, its progress, its improvement and its well-being that facts concerning agriculture, industry, trade, government, pathology and medicine, and all manner of things are collected? Agricultural, industrial, commercial, financial, administrative, medical and other statistics are merely the branches of the enormous tree of humanity, which covers the whole earth with its green foliage and contributes to the development of everything that it sustains and encompasses. Only human statistics, or demography, has the capacity to depict this in its entirety. ${ }^{28}$

The term demography has withstood the test of time, though Guillard's grand aspirations and the moral undertone of his essay no longer resonate. Tendencies towards specialisation and attempts at synthesis were typical of the turbulent development of statistics in France, and the effects would have been felt at the international congress. The programme was shrouded in mystery until the last moment. The members of the preparatory commission were men of disparate temperament and experience. Bureau directors and members of the Institut de France did not always speak the same language. Guillard, whose work - not by coincidence - was published just days before the congress, could not publicly criticise his countrymen, but did express regret about the lack of focus:

We shall be permitted to say that unless all sections concern themselves with the necessity of uniformity (without which science will remain uncertain and open to dispute), and unless that necessity is the beacon that enlightens all discussions of a general and a specific nature, there is a danger that the congress will fail in its objective, and that a gathering of scholars whose aim is to discuss their points of view seriously and purge contradictions will turn out to be a futile exhibition of a literary circle. ${ }^{29}$

The pursuit of uniformity united all statisticians, not just the French. However, disagreement ensued whenever an attempt was made to define this endeavour in specific terms. The international setting did not make the task any easier. Differences of opinion between scientists and between countries played a role at the congress of 1855. More cautious than their Belgian predecessors, the French organisers presented the participants with a list of questions and 
proposals rather than a set of propositions. They decided to hold simultaneous discussion sessions for experts in the morning, followed by an afternoon plenary session at which decisions would be adopted publicly. The meetings were held in the parliament building. Though the official record states that 365 people registered for the congress, only 250 actually attended, the majority of whom (220 according to Dieterici) were residents of France.

The minister of Agriculture and Trade, Eugène Rouher, delivered the opening address in the main hall of the Corps législatif. His grand words were appropriate for the occasion: international statistics would reveal which laws and institutions were most conducive to love of family and country, to mitigating suffering and to elevating the hearts and minds of the people. The modesty of his subsequent observation demonstrated a greater sense of realism: the objective of international statistics could not be realised by one gathering or one country; the Paris congress was therefore only a building block. After Rouher, the directors of the national statistical bureaus took it in turns to address the congress. The participants had their first opportunity for discussion in the special sessions that followed.

Dieterici attended a session on agricultural statistics. He noted that thirty Frenchmen, but only a handful of 'foreigners', took part. In his personal report, he remarked that during the session tasks were assigned to the participants in a 'rather loud and disorderly' manner. There was no substantive discussion on the first day. 'Everything had a rather parliamentary character', he noted disapprovingly, and the scientific element was neglected. ${ }^{30}$ To him, apparently, the modifier 'parliamentary' stood for boisterous and unprofessional.

Certainly Dieterici's opinion had a strong authoritarian and nationalist tint. Most French participants were proud of their achievements during the congress. Even Guillard, who had been cautiously critical of the representatives of government statistics in his book on demography, joined in the discussion wholeheartedly. He made various attempts to elicit statements about the organisation of statistics from the congress. He also participated in the session on statistics of large cities, a subject that had been disposed of in 1853 with declaration of intent, which stated in consideration of the particular phenomena relating to public health, morality, crime et cetera which occur in densely populated agglomerations, special and detailed statistics must be compiled for all large cities. ${ }^{31}$ The other themes addressed by the 1855 congress were agriculture statistics, transport statistics, foreign trade, insurance, crime and justice, poverty, disease and mortality.

Some of these subjects had been on the agenda of the Brussels congress, but it was clear from the start that little progress had been made internationally. Furtive attempts to formulate joint guidelines for organising national statistics had produced only meagre results. The establishment of central statistical commissions, another topic addressed in 1853, was on the agenda again. The director of government statistics in Austria, Karl von Czoernig, was the rapporteur for the general debate preparation session. His report provides a good overview of the way statistics was organised in the mid-nineteenth century. 
Czoernig observed that the science of statistics was new and the use of statistics for the purposes of public administration was newer still. While the need to acquire data of this kind was obvious, different paths were being taken to achieve the goal. Only a few countries had statistical bureaus, and where they did exist, they were often bound by the domain of the ministry under whose remit they came. In some cases, duplicate information was collected via different channels. Moreover, information sharing between government and science left much to be desired. According to Czoernig, there was only one remedy: national statistics would have to be centralised. He compared the task of the statistician with that of other scientists, such as astronomers or physicians:

As an astronomer must study the universe to explain the orbit of celestial bodies; as the physician must produce an exact depiction of all the body's organs and every function of the human organism to understand the mechanism of life; to understand and explain the complex mechanism of the life of societies, the statistician must consider the entirety of all possible manifestations of that life. ${ }^{32}$

This objective was attainable only by means of central statistical commissions, based on the Belgian model. Czoernig asserted that France needed a central commission: though more statistical investigations were conducted in France than in any other country, there was no centralisation and the practical value of government statistics was not always obvious. England had a similar problem: there was plenty of statistical material but no uniformity. The German Zollverein had already begun coordinating its surveys and Austria's Direction der administrativen Statistik was, in practice, tantamount to a central commission. Czoernig's Austrian colleague Louis Debrauz supported him and suggested publishing the proposal in the French government gazette, the Moniteur, because he anticipated that the national delegates would not have a mandate from their respective governments to approve decisions adopted by the congress.

All the delegates dreamt of uniformity in statistical practice. They wanted to see standardisation in bureaucracy and organisation, terminology and choice of research topics, and this came up for discussion intermittently. Before the Paris congress began, Ernst Engel, who was representing Saxony, made a plea for a multilingual statistics dictionary. ${ }^{33}$ During the congress, the Spanish clergyman Bonifacio Sotos Ochando proposed a universal language, a precursor of Esperanto. The participants discussed making French the official language of the congress. Debrauz strongly supported this suggestion, because French was the main language of diplomacy and, in his opinion, science needed a new universal language. However, the assembled statisticians were reluctant to take a decision on the matter and left it up to the organisers of the next congress.

Consensus on the standardisation of currency units, weights and measures - a fervent desire of the French organisers - proved equally difficult to reach. The French delegate Hippolyte Peut, a member of the Paris-based Societé d'Économie Politique, made an impassioned plea in favour of adopting French 
units of measurement, e.g. the metre, as Piedmont, Switzerland and Belgium had already done. Dieterici noted that the goal of standardisation met with approval all around, but the congress could do no more than urge governments to follow the statisticians' lead. Voilà tout. The national authorities had full control over such matters, and Dieterici believed wholeheartedly that this was the way it should be. Moreover, he had doubts about whether the decimal system was the best conceivable system. He had attended a meeting of the Societé d'Économie Politique at which this subject was discussed extensively. In his opinion, the people - the French population included - were not used to counting in units of ten. To him, the discussion was somewhat academic (though, all things considered, he probably appreciated that). What he found most irritating was the self-importance of the French and their assumption that France could influence the domestic agendas of other states.

The French preparatory commission, at the instigation of Alfred Legoyt, considered the issue of population counts, which had also been discussed in depth in 1853, but it turned out that there was no scope for dealing with this matter at the congress. Vexing questions concerning the use of census agents, sanctions for evasion and deception, systemisation of occupation nomenclature, definitions of households and family and enumeration of dwellings remained unanswered. These were the questions that the congress should have tackled to demonstrate that an international statistics framework was a viable pursuit. The fact that the population census would not appear on the agenda again until the London congress in 1860 did not bode well for progress on this front.

The statistics of large cities was an important theme at the Paris congress. This new form of statistical research encompassed every aspect of the nineteenthcentury debate on statistics. Growing urbanisation and the attendant misery was the dark side of industrial capitalism, so it is not surprising that statisticians focused their attention on the city as an object of numerical study. The congress in Brussels had pointed the way to urban statistics, but it was up to the French preparatory commission to develop an appropriate programme. The task was in good hands. The French were very proud of Chaptal's pioneering work in Paris in the 1820s. Moreover, the Paris Chamber of Commerce had commissioned an extensive census of Parisian industry in 1847-1848 and published the results in 1851. Though this survey had a limited objective, Legoyt believed that this 'work, worthy of good citizens, was a perpetual and remarkable lesson benefiting the social order.

These were not empty words. The revolution of spring 1848 was accompanied by waves of public protest. The workers took to the streets to protest the rapid growth of unemployment and the closure of national, government-supported workshops. Knowledge concerning the state of business and industry in the capital was not only of economic interest, it was also of value to political leaders. The members of the Chamber of Commerce - the factory and workshop owners who were involved in the industrial statistics - were keen to project an image of a stable economic sector in which workers were simply employees and had no political demands. Both workers and their bosses were classified as industriels. 
This took the edge off the socialist rhetoric, which emphasised the differences between the two groups. In other ways, too, the Statistique de l'industrie was an endorsement of bourgeois morality. Married workers were found to have the highest ethical values. They distanced themselves from worldly lusts and passions and took shelter in the tranquillity of the family. 'Written in the wake of 1848, it [the Statistique de l'industrie] was intended to dispute the revolution's most radical economic and political claims and to reassert a vision of economic organisation that had been severely challenged, especially by socialist theorists. ${ }^{34}$

References to statistics of the Paris Chamber of Commerce such as those of Legoyt were actually allusions to the desire the bourgeoisie had for social and political control. This desire for control stemmed from the uncertainties that were rife in nineteenth-century society, despite the many benefits that the middle class enjoyed. Epidemics, disease, popular uprising, crime and bankruptcy were perpetual threats, particularly in the eyes of the emancipated citizen, who had been liberated from so many chains since the French Revolution. Certainty breeds desire for even greater certainty. This was the reason that insurance statistics were included in the programme. As the origin of both good and evil, the city was the primary focus of attention.

That said, the creation of an international framework for statistics of large cities was more than a conservative project. Urban statistics incorporated virtually all the substantive and ideological aspects of general statistics. Dupin took it upon himself to report on this topic to the congress, and did it with panache. There were innumerable subjects to study: topography, surface area, publiclyand privately-owned buildings, roads, population, public health, consumption, trade and industry, local government, municipal finances, public amusement, poor relief, safety, crime, education and churches. Each of these themes was broken down into subtopics, resulting in a list of questions several pages long. It was no coincidence that hygiène publique was the theme that inspired the most questions. There was enormous interest in sewage systems, water mains, bathhouses, medical care, health police, cemeteries and prostitution. A separate questionnaire was drafted to collect data on urban trade and industry and appended to the list. On paper, it was a magnificent project that appealed to the classifying, statistical mind. However, in practice it was almost unworkable in this form.

This did not stop Guillard from remarking, as a congress participant, that some issues pertinent to large cities were missing from Dupin's project. For example, he thought there should be a way to determine whether abandoned children were given shelter inside or outside the city, and whether the number of children born out of wedlock was included in the urban births figure, even if the mothers were from outside the city. Like all statisticians, he had boundless optimism and faith that it was possible to know everything.

There were also smouldering rivalries between cities. The English delegates praised London's statistics and the public sanitation measures the city was implementing. They wanted to include specific questions concerning what they 
considered to be their areas of expertise, such as water supply.

The urban statistics project foreshadowed future developments. The number of urban statistics bureaus gradually increased. Germany, at the forefront of this development, held a national conference on urban statistics in 1879. By 1900 there were nearly one hundred urban statistic bureaus in Europe. The origins of the Union Internationale des Villes, or International Union of Local Authorities, founded in 1913 could be traced back to the initiatives that were explored in Paris in 1855.

The focus on statistics of large cities was both a low point and a high point in the international statistics movement. Statistique Internationale des Grandes Villes, edited by Joseph Körösi, director of the statistics bureau of Budapest, was published in two volumes in 1876 and 1877 . Notwithstanding the reports issued by the participants, these were the first official publications of the international statistical congresses that had been held thus far. They fulfilled the promise that Dupin had made in 1855. The subject matter of these volumes (population dynamics and finance) show that only a small portion of the original wish-list was carried out.

The countryside also drew the attention of the statisticians. The congress of 1853 had taken a number of decisions regarding the agricultural census, a subject at least as complex as that of the population census. What was the best month in which to conduct an agricultural census? How often should the census be repeated? Who should be given the task of collecting the data: civil servants, who could easily be suspected of having fiscal motives; ordinary citizens, who would probably lack the right expertise and would demand payment for their efforts; or a special commission, as in France? And what kind of data should be collected and how?

All of these questions and more were raised by the organiser of the agriculture section, Marie Joseph Monny de Monnier, a department head at the Ministry of Trade and Agriculture. The rapporteur for the section, Maurice Block, emphasised the tremendous scope of the problems involved in collecting agricultural statistics. To begin with, there was no government agency that concerned itself directly with agricultural production; it fell to outsiders to classify the questions and data, but first they would have to reach a consensus. Every country had come up with solutions, but on comparison they were found to be very different.

Block referred to ponderous discussions in the closed morning sessions that produced few practical compromises. For example, the participants had a preference for paid, government-appointed census agents, but wanted to maintain commissions, provided that they had the capacity to manage the organisation of the counts and verification of the numbers adeptly. Then there was the matter of how the data should be obtained: by interviewing each agricultural producer or having them fill in questionnaires, or by consulting the land registry to ascertain the surface area that was devoted to each type of land use and then calculate the total production 'based on a certain number of weighings and measurements to be carried out with care and in a variety of circumstances' 
- i.e. by means of extrapolation. ${ }^{35}$

Some countries did not maintain a land registry, and many people were sceptical of extrapolation, because they regarded the results of this method as inherently non-representative. The agriculture section endorsed the establishment of land registries, but left it up to each country to decide which methods would produce the best results, given the local situation. With regard to periodicity, too, each country would be free to decide which interval was most appropriate. They did, however, opt for both annual and decennial surveys with varying degrees of precision in the desired data. So, pragmatism prevailed over the quest for uniformity.

These problems were not resolved during the open deliberations, when the assembled participants were given the opportunity to express their opinions on the various proposals. On the contrary, the French could not even agree among themselves. Napoléon Foch, secretary-general of the Hautes-Pyrénées department and father of the famous field marshal, was utterly opposed to the idea of paying census agents. As he saw it, paying agents had not led to improvements anywhere the practice existed. Furthermore, he believed that remuneration was a road to nowhere, because statistics would soon become unaffordable. By contrast, his countryman Hippolyte Peut, a member of the Société d'Économie Politique, believed that paying agents was the only way to guarantee accuracy. This difference of opinion echoed the exchanges that had taken place during the morning sessions.

Dieterici, who witnessed the debate and reported on it to his minister, observed how the French once again commandeered the subject at hand. Block was resolved that only civil servants should be assigned to the task of collecting agricultural data. In Dieterici's opinion, this was a bureaucratic tactic typical of the French. The ministry was primarily interested in defining as many classifications and categories as possible, which was bound to result in chaos. The only thing the ministry and the statistics bureau accomplished, wrote Dieterici, was to make it possible to give a plethora of secondary bodies and persons assignments and instructions, which became the ends rather than the means. He felt confirmed in his views by a French mayor who believed that appointing special civil servants was completely unnecessary because no one was better informed than the local authorities about the situation within their own territory. Moreover, the French assumed that every country maintained a land registry. The Portuguese delegate reported that his country, like half of the states of Europe, had no land registry, and even in France cadastral data was not consistently reliable.

A difference of opinion was also apparent in the discussion about counting livestock, another topic that seemed at first glance unlikely to stoke controversy. However, when it emerged that the French were pushing for an annual inventory in addition to a decennial count - because France had a shortage of livestock and wanted to know whether the West Prussian provinces had surpluses - Dieterici lost his composure. He stated that for fifty years Prussia had conducted triennial counts and that the country had no intention of altering this highly satisfactory 
practice merely to accommodate the needs of the French.

The debate on agricultural statistics reveals how difficult it was to achieve genuine, workable compromises. People were more willing to introduce a new type of statistics than to change an established practice. The national delegates held fast, in some cases with great obstinacy, to the procedures they were familiar with, and merely took note of the other ideas that were put forward.

In France, there were different 'styles' of statistics, each of which had been more or less institutionalised by the mid-nineteenth century. Government bodies favoured descriptive statistics, a style that was based on combining 'hard' numbers and qualitative descriptions and assumed that reality could be interpreted directly from numbers. During the revolutionary period and under Napoleon I, the foundations had been laid for identifying statistics as an element of good government. Statistics had served so well as the language of bureaucracy that it had become an inextricable part of national government, even though some political regimes (and France experienced quite a few regime changes in the nineteenth century) were less favourably disposed towards it than others. Scientific statistics, in which trends and probabilities dominated the style of discourse, was firmly anchored in the public sphere. The sanitarians, under the leadership of Villermé, were particularly adept at propagating and using statistics as a weapon in their struggle. Members of institutions like the Académie des Sciences Morales et Politiques and the Société d'Économie Politique saw statistics as a means of shaping society in accordance with liberal values. Villermé, who remained active until his death in 1863, supported the establishment of the Sociéte de statistique de Paris in 1860. The Société tried to serve as a bridge between 'official' statistics and the various groups of users, of which the moral statisticians were the most active. The international congress's aspiration of centralisation was finally achieved in 1885, when the government set up the Conseil supérieur de la statistique.

Though the spheres in which statistics was practiced in France overlapped, the convictions and aspirations of statisticians were often irreconcilable. This was the reality in France, and the same paradox was even more clearly evident at the international forum convened in Paris in 1855. National incongruities stood in the way of the consensus to which the statisticians aspired. Uniformity was their common goal, but they were driven apart by the consequences of pursuing that endeavour. Proposals to standardise practices in urban and agricultural statistics provoked considerable discussion, but competition and envy made compromise difficult.

\section{Notes}

1 GStA PK, I. Hauptabteilung, Repositur 77, Ministerium des Innern, Abteilung I, Section 13, No. 99, Bd. 1 Statistische Generalversammlungen des In- und Auslandes (1853-1859), report by Dieterici to the Minister of the Interior, Berlin, 18 October 1855.

2 Compte rendu de la deuxième session du congrès international de statistique réuni à Paris les 10, 12, 13, 14 et 15 septembre 1855 (Paris 1856), XXVII. 
3 Correspondance mathématique et physique 3 (1827), 253-255. The map showing the state of popular education in the Netherlands, designed by Somerhausen, can be found in Part II of C. Dupin, Forces productives et commerciales de la France (Paris 1827, copy Universiteitsbibliotheek Universiteit van Amsterdam).

4 É. Smits, Nationale statistiek. Ontwikkeling der een-en-dertig tabellen ... (Brussels 1827), p. 65.

5 C. Dupin, Forces productives et commerciales de la France, I (Brussels 1828), XV-XVI.

6 Compte rendu de la deuxième session du congrès international de statistique, p. 14.

7 Ibid., p. 15.

8 L. Daston, 'Rational Individuals versus Laws of Society: From Probability to Statistics', in L. Krüger, L.J. Daston, M. Heidelberger (eds.), The Probabilistic Revolution, I, Ideas in History (Cambridge, MA and London 1987), p. 300.

9 M.-N. Bourguet, Déchiffrer la France. La statistique départementale à l'époque napoléonienne (Paris 1988), p. 101.

10 Cited in ibid., p. 105.

11 Ibid., pp. 64-82.

12 Cited in M. Armatte, 'Une discipline dans tous ses états: la statistique à travers ses traités (1800-1914)', Revue de synthèse 112 (1991), p. 171.

13 Cited in Bourguet, Déchiffrer la France, pp. 80-81.

14 Cited in F. Sofia, Una scienza per l'amministrazione. Statistica e pubblici apparati tra età rivoluzionaria e restaurazione, (Rome 1988), p. 104.

15 M.-N. Bourguet, 'Décrire, Compter, Calculer: The Debate over Statistics during the Napoleonic Period', in Krüger, Daston, Heidelberger (eds), The Probabilistic Revolution, I, p. 311.

16 S.J. Woolf, Napoleone e la conquista dell'Europa (Rome/Bari 1990), p. 108.

17 Bourguet, Déchiffrer la France, pp. 301-313.

18 S.J. Woolf, 'Towards the History of the Origins of Statistics: France 1789-1815', in J.-C. Perrot and S.J. Woolf, State and Statistics in France 1789-1815 (London 1984), pp. 132-155.

19 Recherches statistiques sur la ville de Paris et le département de la Seine, Année 1821 (Paris 1823) I, III; see also B.-P. Lécuyer, 'The Statistician's Role in Society: the Institutional Establishment of Statistics in France', Minerva. Review of Science, Learning and Policy 25 (1987), 41.

20 'Extrait d'un rapport fait à son excellence le ministre de l'Intérieur par monsieur le comte de Chabrol, conseiller d'État, préfet du département de la Seine (3 juillet 1818)', in Recherches statistiques, LXXXI.

21 Ibidem, LXXXVIII.

22 J.-P. Chaline, 'Louis-René Villermé: l'homme et l'œuvre', in L.-R. Villermé, Tableau de l'état physique et moral des ouvriers employés dans les manufactures de coton, de laine et de soie (Paris 1989; 1st edn 1840), p. 15.

23 A.F. La Berge, Mission and Method. The Early Nineteenth-Century French Public Health Movement (Cambridge 1992), pp. 59-75.

24 A.M. Guerry and A. Balbi, Statistique comparée de l'état de l'instruction et du nombre des crimes dans les divers arrondissements des académies et des cours royales de France (n.p. 1829).

25 A.M. Guerry, Essai sur la statistique morale de la France (Paris 1833), p. 51.

26 M. Perrot, 'Premières mesures des faits sociaux: les débuts de la statistique criminelle en France (1780-1830)', in Pour une histoire de la statistique, I (Paris 1977), 127.

27 A. Moreau de Jonnès, Éléments de statistique comprenant les principes généraux de cette science et un aperçu historique de ses progrès (Paris 1847), p. 1.

28 A. Guillard, Éléments de statistique humaine ou démographie comparée (Paris 1855), XXV-XXVI.

29 Ibid., XXXII.

30 GStA PK, I. Hauptabteilung, Repositur 77, Ministerium des Innern, Abteilung I, Section 13, Nr. 99, Bd. 1 Statistische Generalversammlungen des In- und Auslandes (1853-1859), letter from Dieterici to the minister of the Interior, Berlin, 25 March 1857, p. $282 \mathrm{f}$.

31 Compte rendu des travaux du congrès général de statistique (Brussel 1853), p. 165. 
32 Compte rendu de la deuxième session du congrès international de statistique, pp. 367-368.

33 Ibid., XXXII.

34 J.W. Scott, 'Statistical Representations of Work: The Politics of the Chamber of Commerce's Statistique de l'Industrie à Paris, 1847-48', in S.L. Kaplan and C.J. Koepp (eds), Work in France. Representations, Meaning, Organization, and Practice (Ithaca and London 1986), p. 363.

35 Compte rendu de la deuxième session du congrès international de statistique, p. 389. 